\title{
Aripiprazole in bipolar disorder: clinical strategies to maximize efficacy and tolerability
}

\author{
Andrea Fagiolini \\ From $1^{\text {st }}$ International Congress on Neurobiology and Clinical Psychopharmacology and European \\ Psychiatric Association Conference on Treatment Guidance \\ Thessaloniki, Greece. 19-22 November 2009
}

\begin{abstract}
A number of double-blind, randomized, controlled trials have confirmed the clinical efficacy of aripiprazole in bipolar disorder and schizophrenia. Aripiprazole is the prototype of the 'third generation' atypical antipsychotics, or dopamine-serotonin- stabilizers and is characterized by a relatively low risk of inducing metabolic adverse effects, causing sedation and other side effects such as hyperprolactinemia. As a partial agonist at dopamine D2 receptors, aripiprazole acts as a functional antagonist in the mesolimbic dopamine pathway, where excessive dopamine activity is thought to cause positive symptoms, but acts as a functional agonist activity in the mesocortical pathway, where reduced dopamine activity is thought to be associated with negative symptoms and cognitive impairment. This presentation will review the available research data on the efficacy of aripiprazole in bipolar disorder and discuss how this data translate in the real world clinical practice and what the best strategies are to maximize the efficacy and tolerability of this medication.
\end{abstract}

Published: 22 April 2010

doi:10.1186/1744-859X-9-S1-S60

Cite this article as: Fagiolini: Aripiprazole in bipolar disorder: clinical strategies to maximize efficacy and tolerability. Annals of General Psychiatry 2010 9(Suppl 1):S60.
Division of Psychiatry, University of Siena School of Medicine, Siena, Italy
Submit your next manuscript to BioMed Central and take full advantage of:

- Convenient online submission

- Thorough peer review

- No space constraints or color figure charges

- Immediate publication on acceptance

- Inclusion in PubMed, CAS, Scopus and Google Scholar

- Research which is freely available for redistribution

Submit your manuscript at www.biomedcentral.com/submit
C Biomed Central 